ВІСНИК

ОДЕСЬКОГО НАЦІОНАЛЬНОГО

МОРСЬКОГО УНІВЕРСИТЕТУ

№ 1 (61), 2020
HERALD

OF THE ODESSA NATIONAL

MARITIME UNIVERSITY № $1(61), 2020$

УДК 621.833.1:539.319

DOI 10.47049/2226-1893-2020-1-140-153

\title{
ВИЗНАЧЕННЯ НАПРУЖЕНЬ І ДЕФОРМАЦИЙ НЕСУЧОЇ СИСТЕМИ ПРИЧАЛЬНОГО КОНТЕЙНЕРНОГО ПЕРЕВАНТАЖУВАЧА ПОРТАЛЬНОГО ТИПУ ЧИСЛОВИМИ МЕТОДАМИ
}

\section{В.Ф. Оробей}

д.т.н., професор кафедри динаміки, міцності машин та опору матеріалів інституту машинобудування та транспорту

Одеський національний політехнічний університет, м. Одеса, Украйна

\section{O.О. Немчук}

к.т.н., проректор з наукової роботи, доцент кафедри

«Підйомно-транспортні машини та інжиніринг портового технологічного обладнання»

Одеський національний морський універсиет, м. Одеса, Украйна

О.М. Лимаренко

к.т.н., завідувач кафедри динаміки, міцності машин

та опору матеріалів інституту машинобудування та транспорту

\section{О.А. Романов}

магістр, наук. співробітник кафедри динаміки, міцності машин та опору матеріалів інституту машинобудування та транспорту

Одеський національний політехнічний університет, м. Одеса, Україна

Анотація. Для розрахунку напружень $i$ деформацій елементів несучої системи причального контейнерного перевантажувача застосовано метод скінчених елементів та метод граничних елементів. Розроблена методика розрахунку металоконструкиії підйомно-транспортних машин, де враховуються підкріплюючі елементи, які присутні в стрілі $і$ в порталі.

При застосуванні метода скінченних елементів розглянуто граничні умови задачі, які максимально наближені до реальних, що впливає на точність результатів розрахунку. Портал і стріла розглядаються як тонкостінні системи, які знаходятьбся під дією розподіленого по деякому закону навантаження від взаємодії з сполученими деталями. Визначено параметри міцності і жорсткості елементів несучої системи причального контейнерного перевантажувача портального типу.

Проведено дослідження на базі методу граничних елементів $i$ методу скінченних елементів, із загальним застосуванням методів комп'ютерного моделювання. При застосуванні метода граничних елементів для просторових стержневих систем враховано всі внутрішні силові фактори.

Ключові слова: метод граничних елементів, метод скінченних елементів, напружено-деформований стан, підйомно-транспортні машини, причальний контейнерний перевантажувач, міџність, жорсткicmb.

() Оробей В.Ф., Немчук О.О., Лимаренко О.М., Романов О.А., 2020 
ВІСНИК

ОДЕСЬКОГО НАЦІОНАЛЬНОГО

МОРСЬКОГО УНІВЕРСИТЕТУ

№ 1 (61), 2020
HERALD

OF THE ODESSA NATIONAL

MARITIME UNIVERSITY № 1 (61), 2020

УДК 621.833.1:539.319

DOI 10.47049/2226-1893-2020-1-140-153

\section{ОПРЕДЕЛЕНИЕ НАПРЯЖЕНИЙ И ДЕФОРМАЦИЙ НЕСУЩЕЙ СИСТЕМЫ ПРИЧАЛЬНОГО КОНТЕЙНЕРНОГО ПЕРЕГРУЖАТЕЛЯ ПОРТАЛЬНОГО ТИПА ЧИСЛЕННЫМИ МЕТОДАМИ}

\section{В.Ф. Оробей}

д.т.н., профессор кафедры динамики, прочности машин и сопротивления материалов института машиностроения и транспорта

Одесский национальный политехнический университет, г. Одесса, Украина

\section{А.О. Немчук}

к.т.н., проректор по научной работе, доцент кафедры «Подъемно-транспортные машины и инжиниринг портового технологического оборудования»

Одесский национальный морской университет, г. Одесса, Украина

\section{О.М. Лимаренко}

к.т.н., заведующий кафедрой динамики,

прочности машин и сопротивления материалов института машиностроения и транспорта

\section{О.А. Романов}

магистр, научн. сотрудник кафедры динамики, прочности машин и сопротивления материалов института машиностроения и транспорта ОНПУ

Одесский национальный политехнический университет, г. Одесса, Украина

Аннотация. Для расчета напряжений и деформаций элементов несущей системы причального контейнерного перегружателя применен метод конечных элементов и метод граничных элементов. Представлены модели расчета металлоконструкиий подъемно-транспортных машин, где учитываются подкрепляюшие элементы, которые присутствуют в стреле и в портале. При использовании метода конечных элементов, рассмотрены граничные условия задачи, которые максимально приближенные к реальным, что влияет на точность результатов расчета. Портал и стрела рассматриваются как тонкостенные системы, под действием распределенной по некоторому закону нагрузки от взаимодействия с сопряженными деталями. Определены параметры прочности и жесткости элементов несущей системы причального контейнерного перегружателя портального типа. Проведено исследование на базе метода граничных элементов и метода конечных элементов, на базе применения методов компьютерного моделирования. При применении метода граничных элементов для пространственных стержневых систем учтены все внутренние силовые факторы.

Ключевые слова: метод граничных элементов, метод конечных элементов, напряженно-деформированное состояние, подъемно-транспортные машины, причальный контейнерный перегружатель, прочность, жесткость. 
UDC 621.833.1:539.319

DOI 10.47049/2226-1893-2020-1-140-153

\section{DETERMINATION OF STRESS AND DEFORMATION OF THE CARRYING SYSTEM OF A LANDING - TYPE LANDING CONTAINER LOADER BY NUMERICAL METHODS}

Orobey V.

Doctor of technical sciences, Professor of the Department Dynamics, strength of machines and resistance of materials of the Institute of Mechanical Engineering and Transport ONPU

Odessa National Polytechnic University, Odessa, Ukraine

Nemchuk A.

$\mathrm{PhD}$, Vice Rector of Science

Odessa National Maritime University, Odessa, Ukraine

Lymarenko O.

candidate of technical sciences, head of the Department Dynamics, strength of machines and resistance of materials of the Institute of Mechanical Engineering and Transport ONPU

\section{Romanov $\mathbf{O}$.}

Researcher of the department

of «Dynamics, strength of machines and resistance of materials» of the Institute of Mechanical Engineering and Transport ONPU

\section{Odessa National Polytechnic University}

Abstract. The finite element method and the boundary element method were used to calculate the stresses and deformations of the elements of the carrier system of the mooring container dock. The method of calculation of metal structures of hoisting-and-transport machines has been developed and the supporting elements which are present in the boom and in the portal are taken into account in the mathematical model of the object of study. In applying the finite element method to calculating the finite element method, we consider the boundary conditions of the problem as close as possible to the real ones, which affects the accuracy of the calculation results. The portal and the arrow are considered as thin-walled systems, under the action of the load distributed by some law from interaction with the conjugated parts. The parameters of the strength and stiffness of the elements of the carrier system of the port-type dock container reloader were determined. The study is based on the boundary element method and the finite element method, with the general application of computer simulation methods. When applying the boundary element method for spatial rod systems, all internal force factors are taken into account.

Keywords: boundary element method, finite element method, stressstrain state, hoisting-and-transport machines, mooring container container, strength, rigidity. 
Постановка проблеми. У сучасних умовах в машинобудуванні великого значення набувають питання підвищення експлуатаційних можливостей парку перевантажувальної техніки при одночасному зниженні матеріаломісткості обладнання.

Вирішення цих завдань пов'язане 3 пошуками нових конструктивних форм і удосконаленням існуючих. Сучасний стан обчислювальної техніки i, що особливо важливо, наявність потужного програмного забезпечення дозволяють вирішувати питання міцності та жорсткості підйомно-транспортних машин на високому науковому рівні.

До недавнього часу при проектуванні несучої системи підйомнотранспортних машин головним чином використовувалися спрощені розрахункові схеми, в яких реальні конструкції представлялися у вигляді найпростіших балкових і пластинчастих моделей. Широко застосовувалися емпіричні рекомендації, отримані шляхом узагальнення досвіду роботи існуючих підйомних кранів. Такий підхід $\epsilon$ досить наближеним навіть при вирішенні задач статики, не кажучи вже про питання стійкості і динаміки.

В даний час широке поширення в розрахунковій практиці мають числові методи. Застосування цих методів особливо ефективно для конструкцій зі складною геометрією, 3 розривами фізико-механічних властивостей матеріалу, при складних граничних умовах.

В основі числових методів лежать дискретні розрахункові схеми. В результаті дискретизації континуальної системи з нескінченним числом ступенів вільності наводиться до системи зі скінченним числом ступенів вільності. Одним 3 найбільш поширених числових методів на сьогодні $\epsilon$ метод скінченних елементів (МСЕ), який передбачає явну апроксимацію рішення на малих підобластях - скінченних елементах. Для інтерполяції застосовуються координатні функції, які мають різний порядок.

Теоретичним аспектам МСЕ присвячено багато наукових і дослідницьких робіт. На основі МСЕ працює більшість сучасних універсальних програмних пакетів - ANSYS, Solid Works, NASTRAN та ін.

Одночасно з МСЕ в останні роки активно розвивається інший числовий метод - метод граничних елементів (МГЕ), де основним $є$ не звичайно-різницеві схеми, а інтегральне рівняння задачі і його фундаментальні рішення.

Цей метод має цілий ряд переваг. В МГЕ дискретизації підлягає не вся область об'єкта, а лише його границя, на якій з системи лінійних алгебраїчних рівнянь визначаються необхідні параметри, а стан у внутрішніх точках обчислюється з інтегральних рівнянь.

У роботі пропонується комплексний підхід до розрахунків елементів несучої системи контейнерного перевантажувача, а саме використовувати два різних за архітектурою числових метода - МСЕ та МГЕ.

Такий підхід дозволяє обгрунтувати доцільність застосування тієї чи іншої конструкції і дає можливість розробки і впровадження нових, 
більш точних і ефективних методик розрахунку несучої системи підйомного крану, що призведе до якісного підвищення експлуатаційних можливостей перевантажувальної техніки.

Таким чином, дослідження, спрямовані на розробку науково обгрунтованих методик розрахунку і проектування елементів несучої системи підйомно-транспортних машин, $є$ актуальною науковою проблемою.

Аналіз останніх досягнень і публікацій. Методика розрахунку металоконструкції підйомно-транспортних машин, що застосовується в даний час, наведена в роботі [1], але в математичній моделі перевантажувача не враховуються підкріплюючі елементи які обов'язково присутні в стрілі і в порталі.

В роботі [2] дається розрахунок лише стріли крана, що звісно не відображає всіє картини напружено-деформованого стану несучої системи.

Слід відмітити, що головним завданням розрахунку елементів несучої системи підйомних кранів $\epsilon$ оцінка впливу на міцність i жорсткість дії навантажень різної природи, а також вплив конструктивнотехнологічних факторів [3], проте в наведеному дослідженні виконується аналіз лабораторних зразків без співставлення 3 реальними конструкціями.

В роботах $[4 ; 5]$ при застосуванні для розрахунку метода скінченних елементів спрощено граничні умови задачі, що впливає на точність результатів розрахунку.

В даний час для розрахунку напружень і деформацій елементів несучої системи причального контейнерного перевантажувача застосовують аналітичні та чисельні методи. При використанні аналітичних методів [6-10] портал і стріла розглядаються як тонкостінні системи під дією розподіленого по деякому закону навантаження від взаємодії 3 сполученими деталями. Цілком очевидно, що отримати точне рішення такого завдання не представляється можливим. Для уточнення аналітичного рішення в розрахункову схему вводяться коефіцієнти, одержувані емпіричним шляхом. Дані коефіцієнти використовуються, наприклад, для визначення величин згинальних, зсувних і крутильних жорсткостей балок, що входять до складу розрахункової схеми.

Перевагою аналітичних методів $\epsilon$ їх відносна простота, а також те, що використовувані аналітичні формули наочно показують вплив того чи іншого параметра конструкції на іiі зміщення, наявність можливості швидко порівняти різні варіанти конструктивних рішень.

Разом 3 тим, аналітичні методи мають недоліки - при їх використанні не можна врахувати реальну геометричну форму просторової конструкції підйомно-транспортної машини, місцеві деформації окремих конструктивних елементів. Аналітичні рішення для деталей складної форми мають значну похибку і вимагають коректування за допомогою емпіричних коефіцієнтів, які, в свою чергу, можуть бути застосовані лише 
для обмеженого набору конструкцій, аналогічних тим, для яких $\epsilon$ експериментальні дані. Зазначені недоліки суттєво обмежують можливості застосування аналітичних методів і призводять до необхідності використання чисельних методів розрахунку. Застосування чисельних методів особливо ефективно для конструкцій зі складною геометрією, 3 розривом фізико-механічних властивостей матеріалу, при складних граничних умовах. В основі цих методів лежать дискретні розрахункові схеми. У роботах [6-10] розглядається розрахунок різних конструктивних елементів із застосування числових методів, але при використанні метода граничних елементів для просторових систем не враховуються такі силові фактори як нормальна сила, та поперечне навантаження в горизонтальній площині.

Мета роботи. Метою роботи є визначення параметрів міцності і жорсткості елементів несучої системи причального контейнерного перевантажувача портального типу.

Це потребує розв'язання наступних задач:

1. Провести дослідження на базі методу граничних елементів i методу скінченних елементів, із загальним застосуванням методів комп'ютерного моделювання.

2. Врахувати в математичній моделі перевантажувача підкріплюючі елементи - діафрагми жорсткості, косинки, накладки.

3. Визначити найбільш навантажені ділянки порталу і стріли.

4. Врахувати вплив просторового навантаження на конструкцію крана та граничні умови для реальної конструкції.

5. При застосуванні метода граничних елементів для просторових стержневих систем враховувати всі силові фактори.

Викладення основного матеріалу. Моделювання всієї металоконструкції ПКП, виконано на базі робочих креслень. Побудована модель, апроксимована об'ємними скінченними елементами. Геометричні елементи визначають положення центрів тяжкості поперечних перерізів елементів ПКП.

Елемент має шість ступенів вільності у кожному вузлі - переміщення в напрямках $\mathrm{X}, \mathrm{Y}, \mathrm{Z}$ вузлової системи координат і кутів поворотів навколо цих осей. 
ВІСНИК

ОДЕСЬКОГО НАЦІОНАЛЬНОГО

МОРСЬКОГО УНІВЕРСИТЕТУ
HERALD

OF THE ODESSA NATIONAL

MARITIME UNIVERSITY № 1 (61), 2020

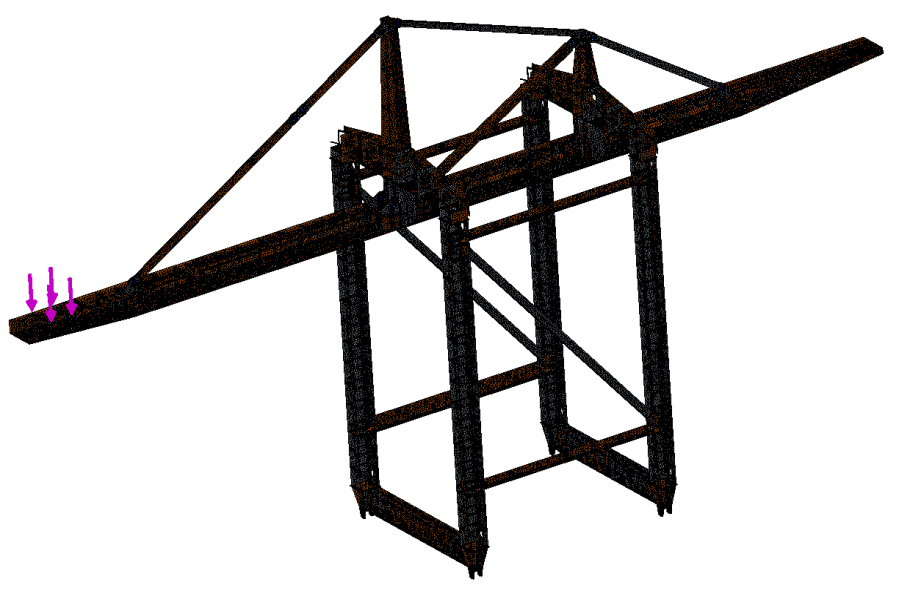

Рис. 1. Математична модель ПКП

з урахуванням підкріплюючих елементів

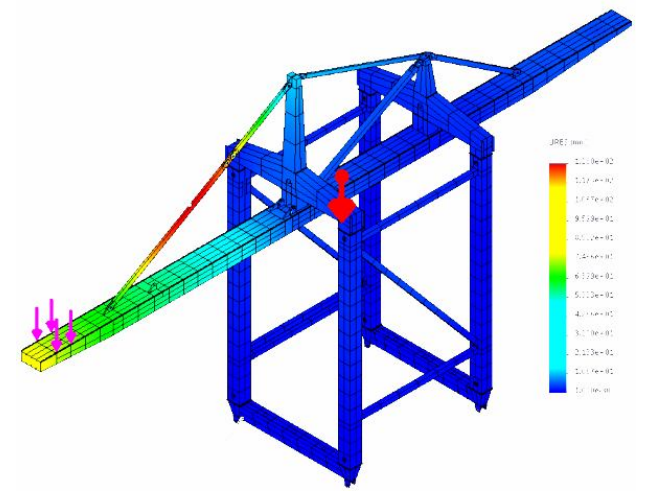

Рис. 2. Переміщення

в моделі причального контейнерного перевантажувача

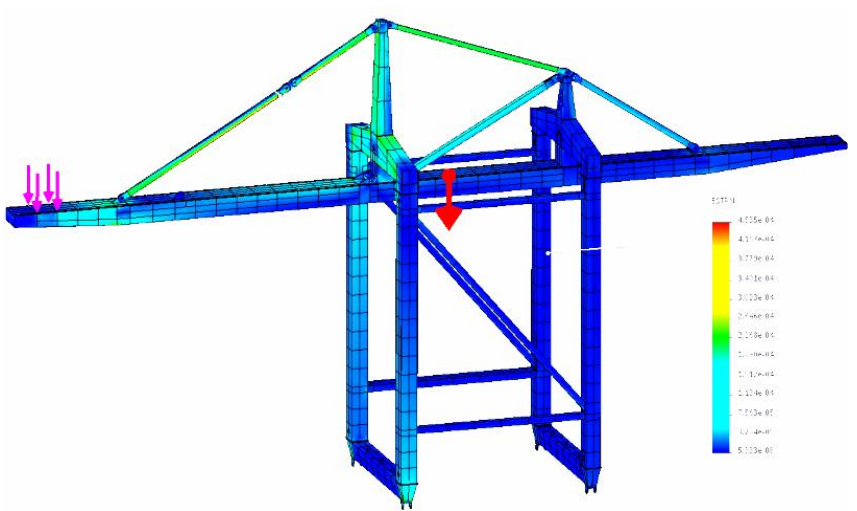

Рис. 3. Поля деформачій

в моделі причального контейнерного перевантажувача 


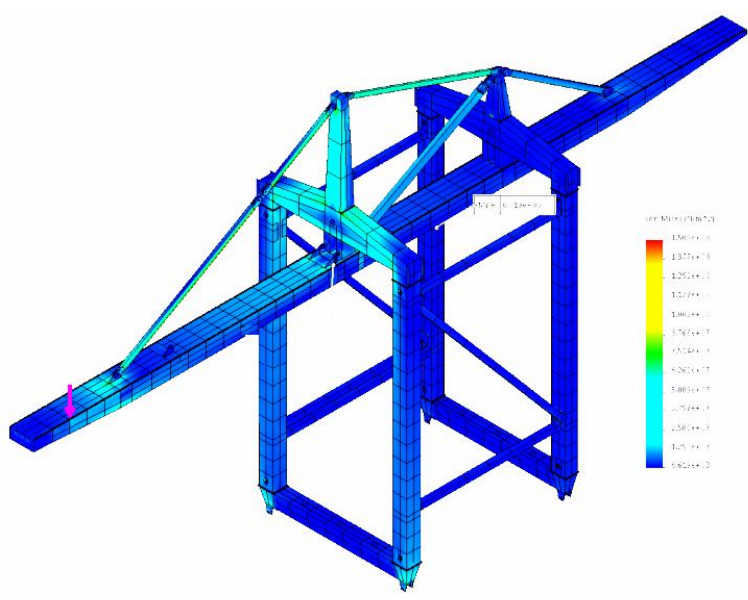

Рис. 4. Еквівалентні напруження, що виникають

в металоконструкиії причального контейнерного перевантажувача

Таблиия 1

\section{Опорні реакиії}

\begin{tabular}{|c|c|c|c|c|c|}
\hline Вузли & FX $(\mathrm{H})$ & FY $(\mathrm{H})$ & FZ $(\mathrm{H})$ & MZ (Нмм) & MY (Нмм) \\
\hline 1 & -82483 & $0,45296 \mathrm{E}+06$ & $-0,16424 \mathrm{E}+06$ & $-0,32569 \mathrm{E}+10$ & $-0,31707 \mathrm{E}+08$ \\
\hline 2 & 79531 & $0,13171 \mathrm{E}+07$ & $-0,19266 \mathrm{E}+06$ & $-0,36086 \mathrm{E}+10$ & $0,47418 \mathrm{E}+07$ \\
\hline 10 & 90781 & 97181 & -97842 & $-0,23875 \mathrm{E}+10$ & $0,29126 \mathrm{E}+09$ \\
\hline 11 & -87829 & $-0,83712 \mathrm{E}+06$ & $-0,14576 \mathrm{E}+06$ & $-0,29369 \mathrm{E}+10$ & $0,18786 \mathrm{E}+09$ \\
\hline
\end{tabular}

Нагружено деформованого стану:

Еквівалентне напруження $\sigma=178,89 \mathrm{MПа;}$

Еквівалентне переміщення $\Delta=206,784$ мм;

Кут повороту $\varphi=0,017$ рад.

Розрахунок елементів ПКП як просторової рами методом граничних елементів.

Розглянемо найбільш навантажені елементи при дії зовнішньої сили із сторони моря - верхня передня балка та передній пілон.

При використанні чисельно аналітичного варіанту методу граничних елементів (ЧА МГЕ) застосуємо для моделювання елементів ПКП метод під конструкцію. Тобто досліджувані елементи представимо як плоско просторову систему.

Елементи просторових рам відчувають вигин, крутіння, зсув i розтягування-стиснення. Рівняння МГЕ одного стержня для просторового випадку буде містити 8 рівнянь. Розглянемо плоско просторовий елемент (рис. 5) найбільш навантаженої ділянки причального контейнерного перевантажувача. 


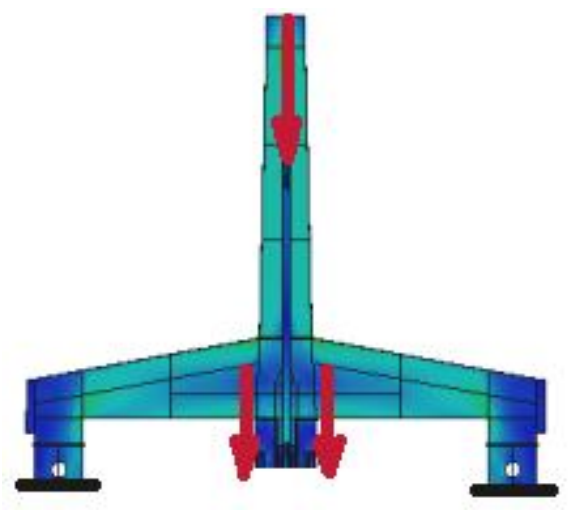

Рис. 5. Розрахункова схема для ЧА МГЕ

За алгоритмом чисельного-аналітичного варіанта методу граничних елементів рама розбивається на три стрижні. Потім формуються матриці МГЕ. Рівняння рівноваги і спільності переміщень параметрів вигину і крутіння для вузла 1 представлені в матриці Y (вісь ОY стрижнів спрямована «вгору»).

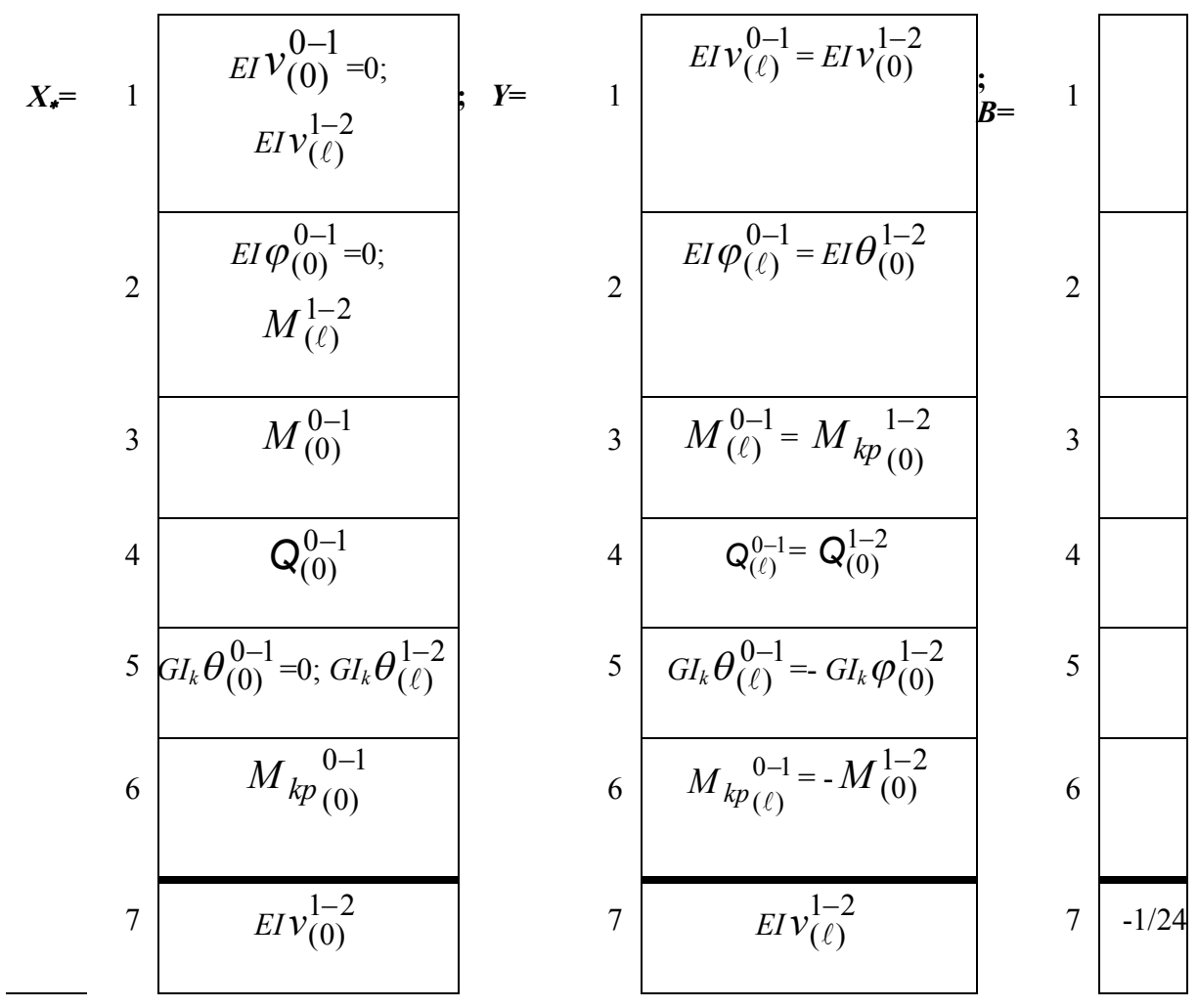


ВІСНИК

ОДЕСЬКОГО НАЦІОНАЛЬНОГО

МОРСЬКОГО УНІВЕРСИТЕТУ

№ 1 (61), 2020
HERALD

OF THE ODESSA NATIONAL

MARITIME UNIVERSITY № 1 (61), 2020

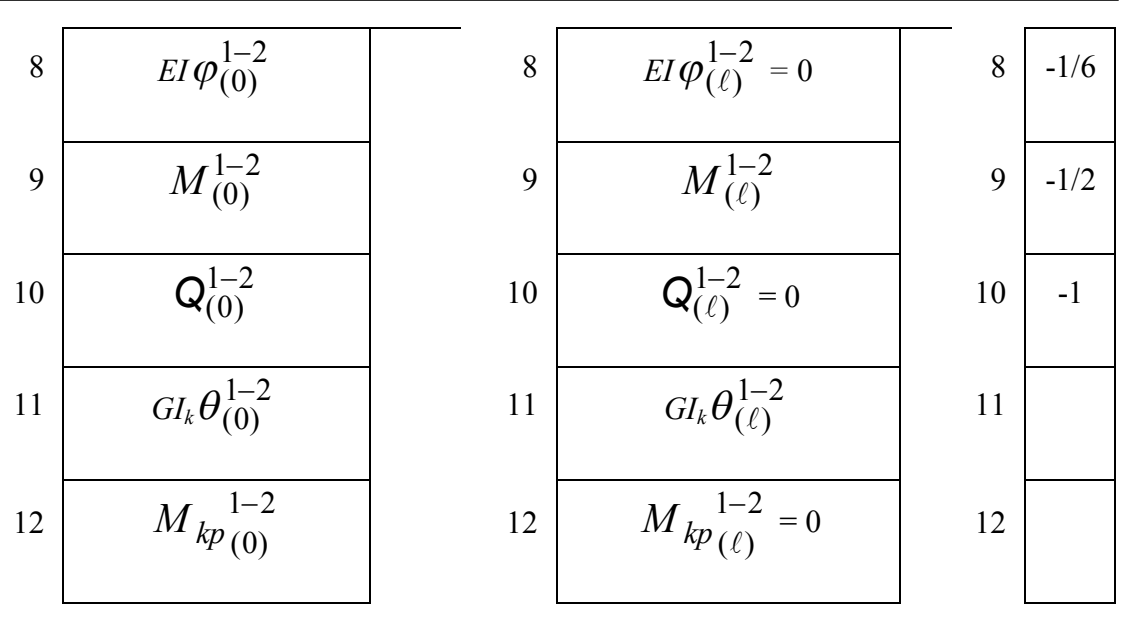

Для виключення буквених символів приймаємо, що $q=l=1$. Топологічна матриця $\boldsymbol{C}$ і система рівнянь МГЕ для рами матимуть вигляд

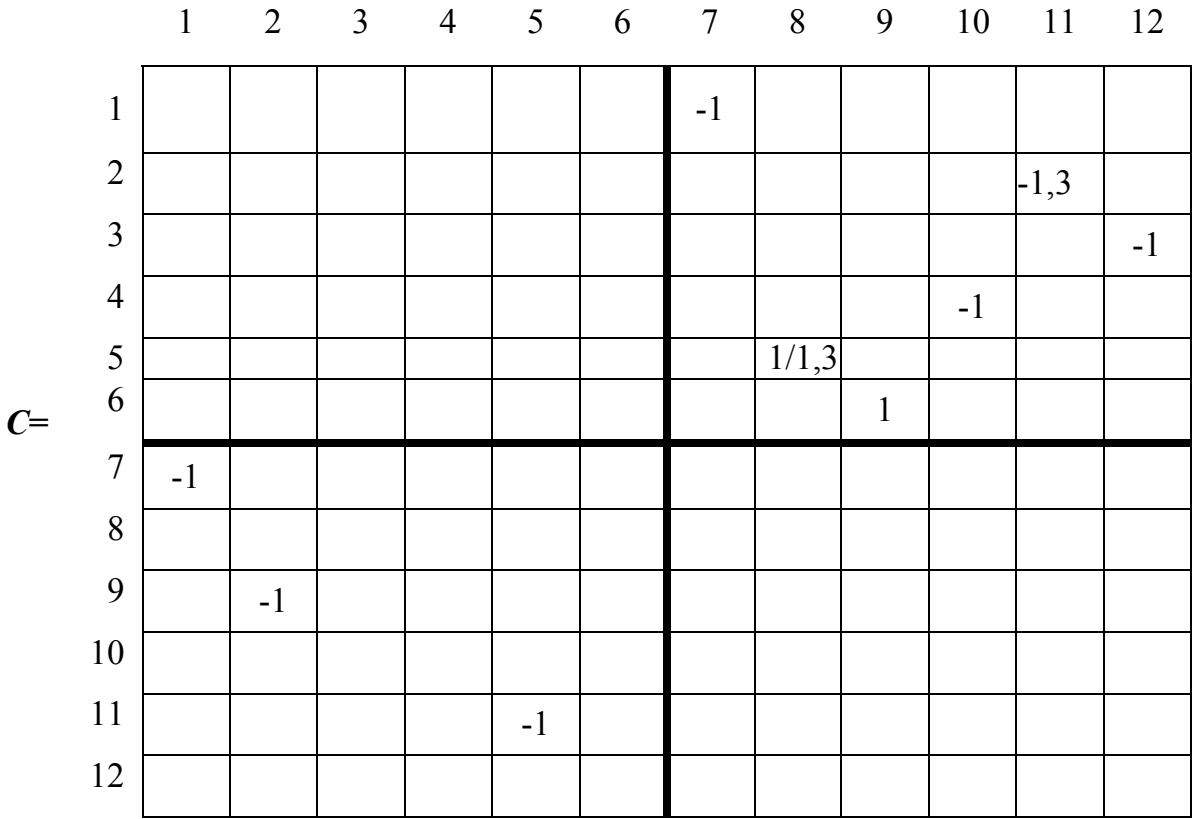


ВІСНИК

ОДЕСЬКОГО НАЦІОНАЛЬНОГО МОРСЬКОГО УНІВЕРСИТЕТУ № 1 (61), 2020
HERALD

OF THE ODESSA NATIONAL MARITIME UNIVERSITY № 1 (61), 2020

\section{$\begin{array}{llllllllllll}1 & 2 & 3 & 4 & 5 & 6 & 7 & 8 & 9 & 10 & 11 & 12\end{array}$}
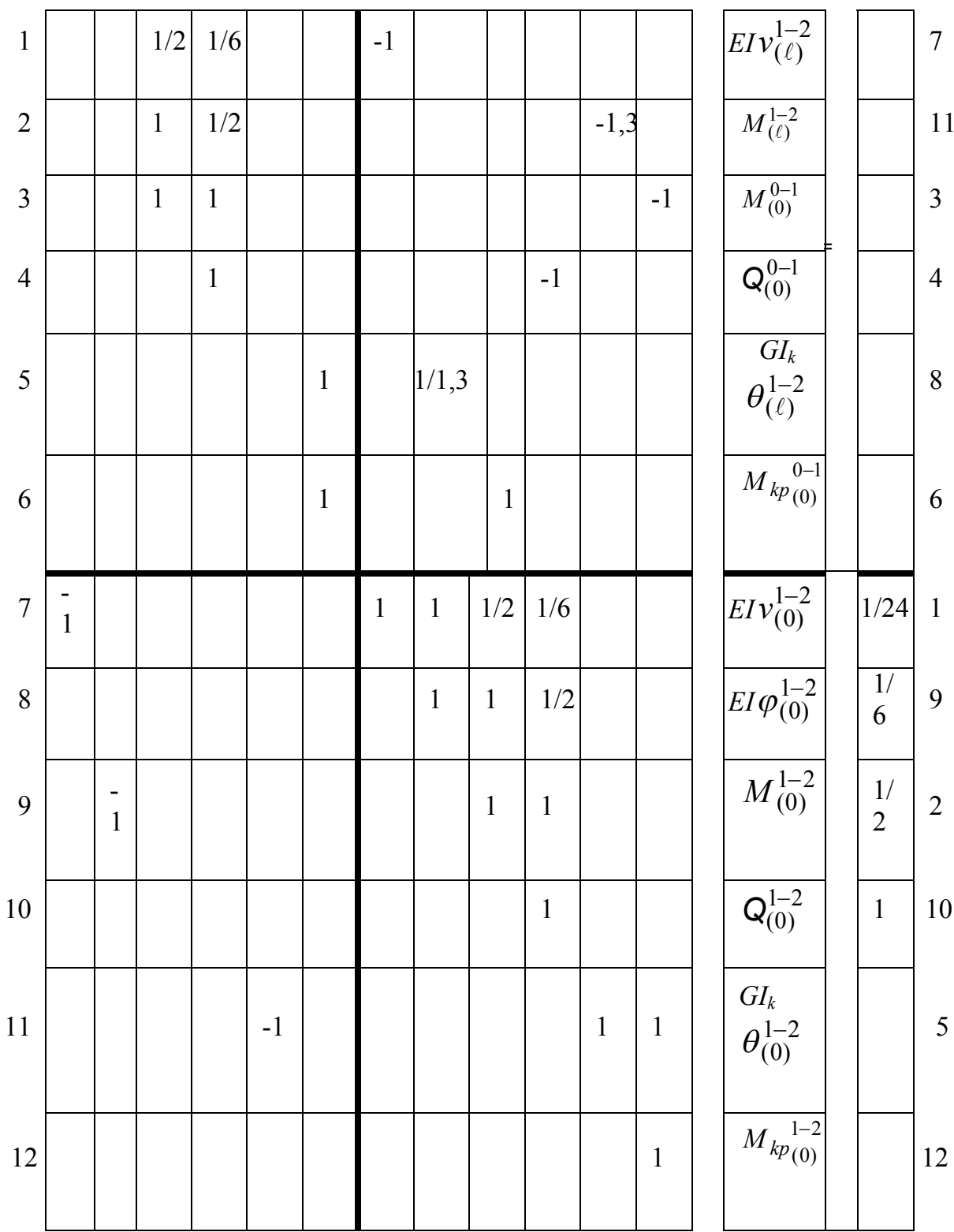

3. Застосовуючи метод Гаусса в середовищі Matlab, отримуємо значення граничних параметрів

$$
E I v_{(\ell)}^{1-2}=-0,4692 q \ell^{4} ; M_{(\ell)}^{1-2}=0,3550 q \ell^{2} ; M_{(0)}^{0-1}=-q \ell^{2} ; \quad Q_{(0)}^{0-1}=q \ell ;
$$




$$
G I_{k} \theta_{(\ell)}^{1-2}=-0,3846 q \ell^{3} ; M_{k p}^{0-1}=0,1449 q \ell^{2} ; \quad E I v_{(0)}^{1-2}=-0,3333 q \ell^{4} ;
$$$$
E I \varphi_{(0)}^{1-2}=-0,1884 q \ell^{3}
$$$$
M_{(0)}^{1-2}=-0,1449 q \ell^{2} ; Q_{(0)}^{1-2}=q \ell ; G I_{k} \theta_{(0)}^{1-2}=-0,3846 q \ell^{3} ; M_{k p}{ }_{(0)}^{1-2}=0,0 .
$$

Значення моменту $M_{(\ell)}^{1-2}$ збігається 3 результатом роботи [2], отриманим методом сил.

Таблиия 2

Розрахункове значення напружень і переміщень в перерізах порталу

\begin{tabular}{|c|c|}
\hline \multicolumn{2}{|c|}{ Опорні частини передньої верхньої балки } \\
\hline МСЕ & МГЕ \\
\hline$\sigma=164,1 \mathrm{MПа}$ & $\sigma=163,25 \mathrm{MПа}$ \\
$\varepsilon=3,581 \cdot 10^{-4}$ & $\varepsilon=3,487 \cdot 10^{-4}$ \\
$\Delta=126,263$ мм & $\Delta=125,496 \mathrm{мм}$ \\
\hline Опорна частина переднього пілону \\
\hline МСЕ & МГЕ \\
\hline$\sigma=179,1 \mathrm{MПа}$ & $\sigma=179,03 \mathrm{MПа}$ \\
$\varepsilon=2,771 \cdot 10^{-4}$ & $\varepsilon=2,7657 \cdot 10^{-4}$ \\
$\Delta=58,2 \cdot 10^{-3}$ мм & $\Delta=58,2 \cdot 10^{-3}$ мм \\
\hline \multicolumn{2}{|c|}{ Кінцевий переріз пілону } \\
\hline МСЕ & МГЕ \\
\hline$\sigma=154,4 \mathrm{MПа}$ & $\sigma=150,65 \mathrm{MПа}$ \\
$\varepsilon=2,625 \cdot 10^{-4}$ & $\varepsilon=2,5692 \cdot 10^{-4}$ \\
$\Delta=60,21 \cdot 10^{-3}$ мм & $\Delta=58,927 \cdot 10^{-3}$ мм \\
\hline
\end{tabular}

Висновки. Визначено параметри міцності і жорсткості елементів несучої системи причального контейнерного перевантажувача портального типу в характерних перерізах.

Проведено дослідження на базі методу граничних елементів i методу скінченних елементів із загальним застосуванням методів комп'ютерного моделювання.

Враховано в математичній моделі перевантажувача підкріплюючі елементи - діафрагми жорсткості, косинки, накладки.

Визначено найбільш навантажені ділянки порталу і стріли.

При застосуванні метода граничних елементів для просторових стержневих систем враховано всі силові фактори.

\section{СПИСОК ЛТТРАТУРИ}

1. Коломієць Л.В. Комп'ютерний та натурний експеримент при визначенні напружень $і$ деформацій металоконструкції причального контейнерного перевантажувача / Л.В. Коломієць, О.М. Лимаренко // Зб. наук. прачь ОДАТРЯ. 2019. № 2(13). С. 32-41. 
ВІСНИК

ОДЕСЬКОГО НАЦІОНАЛЬНОГО

МОРСЬКОГО УНІВЕРСИТЕТУ

№ 1 (61), 2020
HERALD

OF THE ODESSA NATIONAL

MARITIME UNIVERSITY

2. Оробей В.Ф. Применение численных методов к расчету элементов судовых конструкиий / В.Ф. Оробей, А.О. Немчук, А.М. Лимаренко // Вісн. Одеськ. наи. морського ун-ту. 2009. № 26. С. 85-90.

3. Кравчук В.С. Влияние конструктивно-технологических факторов на коэффициент запаса прочности поверхностно-упрочненных деталей машин / В.С. Кравчук, А.М. Лимаренко // Праці Одеського політехнічного університету. 2006. № 1 (25). С. 14-17.

4. Limarenko A.M. The optimization of car engine piston-rod by numerical method / A.M. Limarenko, V.V. Khamray, A.A. Druzhynin // Bicник Одеської державної академії будівництва і архітектури. 2015. Bun. 51, ч. 1. C. 586-589.

5. Лимаренко А.М. Методика расчета рулевого управления с применением модуля программы Solid Works / A.M. Лимаренко, В.В. Хамрай А.А. Дащееко // Материаль 9 международной научнопрактической конференции «Современные исследования $и$ развитие», Болгария, София, 2015. Том 16. С. 11-13.

6. Баженов В.А. Численные методы в механике / В.А. Баженов, А.Ф. Дащенко, Л.В. Коломиеи, В.Ф. Оробей, Н.Г. Сурьянинов. Одесса: Стандарть, 2005. 564 c.

7. Оробей В.Ф. Расчет арок на устойчивость методом граничных элементов / В.Ф. Оробей, А.Ф. Дащенко, А.М. Лима-ренко // Проблеми техніки. Одеса, 2009. № 2. С. 114-123.

8. Orobej $V$. Boundary element method in problem of plate elements bending of engineering structures [Text] / V. Orobey, L. Kolomiets, A. Lymarenko // Metallurgical and Mining Industry. 2015. № 4. P. 295-302.

9. Orobey $V$. Mathematical modeling of the stressed-deformed state of circular arches of specialized cranes [Text] / V. Orobey, O. Daschenko, L. Kolomiets, O. Lymarenko, Y. Ovcharov // Eastern European Journal of Enterprise Technologies. 2017. 5/8(89). P. 4-11.

10. Orobey $V$. Stability of structural elements of special lifting mechanisms in the form of circular arches [Text] / V. Orobey, O. Daschenko, L. Kolomiets, O. Lymarenko // Eastern European Journal of Enterprise Technologies. 2018. 2/7(92). P. 4-10.

\section{REFERENCES}

1. Kolomiets L.V. Kompiuternyi ta naturnyi eksperyment pry vyznachenni napruzhen i deformatsii metalokonstruktsii prychalnoho konteinernoho perevantazhuvacha / L.V. Kolomiets, O.M. Lymarenko // Zb. Nauk. prats ODATRIa. 2019. \# 2(13). S. 32-41.

2. Orobej V.F. Primenenie chislennyx metodov $k$ raschetu e'lementov sudovyx konstrukcij / V.F. Orobej, A.O. Nemchuk, A.M. Limarenko // Visn. Odes. nac. mors'kogo un-tu. 2009. № 26. S. 85-90.

3. Kravchuk V.S. Vliyanie konstruktivno-texnologicheskix faktorov na koe'fficient zapasa prochnosti poverxnostno-uprochnennyx detalej mashin / V.S. Kravchuk, A.M. Limarenko // Praci Odes'kogo politexnichnogo universitetu. 2006. № 1 (25). S. 14-17. 
ВІСНИК

ОДЕСЬКОГО НАЦІОНАЛЬНОГО

МОРСЬКОГО УНІВЕРСИТЕТУ

№ 1 (61), 2020
HERALD

OF THE ODESSA NATIONAL

MARITIME UNIVERSITY

4. Limarenko A.M. The optimization of car engine piston-rod by numerical method / A.M. Limarenko, V.V. Khamray, A.A. Druzhynin // Visnyk Odeskoi derzhavnoi akademii budivnytstva i arkhitektury. 2015. Vyp. 51, ch. 1. S. 586-589.

5. Limarenko A.M. Metodika rascheta rulevogo upravleniya $s$ primeneniem modulya programmy Solid Works / A.M. Limarenko, V.V. Xamraj A.A. Dashhenko // Materialy 9 mezhdunarodnoj nauchno-prakticheskoj konferencii «Sovremennye issledovaniya $i$ razvitie», Bolgariya, Sofiya, 2015. Tom 16. S. 11-13.

6. Bazhenov V.A. Chislennye metody v mexanike / V.A. Bazhenov, A.F. Dashhenko, L.V. Kolomiec, V.F. Orobej, N.G. Sur'yaninov. Odessa: Standart, 2005. $564 \mathrm{~s}$.

7. Orobej V.F. Raschet arok na ustojchivost' metodom granichnyx e'lementov / V.F. Orobej, A.F. Dashhenko, A.M. Limarenko // Problemi texniki. Odesa, 2009. № 2. S. 114-123.

8. Orobej V. Boundary element method in problem of plate elements bending of engineering structures [Text] / V. Orobey, L. Kolomiets, A. Lymarenko // Metallurgical and Mining Industry. 2015. № 4. P. 295-302.

9. Orobey $V$. Mathematical modeling of the stressed-deformed state of circular arches of specialized cranes[Text] / V. Orobey, O. Daschenko, L. Kolomiets, O. Lymarenko, Y. Ovcharov // Eastern European Journal of Enterprise Technologies. 2017. 5/8(89). P. 4-11.

10. Orobey $V$. Stability of structural elements of special lifting mechanisms in the form of circular arches [Text] / V. Orobey, O. Daschenko, L. Kolomiets, O. Lymarenko // Eastern European Journal of Enterprise Technologies. 2018. 2/7(92). P. 4-10.

Стаття надійшла до редакиії 20.02.20

Посилання на статтю: Оробей В.Ф., Немчук О.О., Лимаренко О.М., Романов О.А.Визначення напружень і деформацій несучої системи причального контейнерного перевантажувача портального типу числовими методами // Вісник Одеського національного морського університету: Зб. наук. праць, 2020. № 1(61). C. 140-153. DOI 10.47049/2226-1893-2020-1-140-153.

Article received 20.02.20

Reference a JournalArtic: Orobey V., Nemchuk A., Lymarenko O., Romanov O. determination of stress and deformation of the carrying system of a landing - type landing container loader by numerical methods. 1(61), 140-153 // Herald of the Odessa national maritime university. DOI 10.47049/2226-1893-2020-1-140-153. 